\title{
Author Correction: Will SARS-CoV-2 variants of concern affect the promise of vaccines?
}

\section{Ravindra K. Gupta}

Correction to: Nature Reviews Immunology https://doi.org/10.1038/s41577-021-00556-5, published online 29 April 2021.

In the original version of this Comment article, the author referred to the P681H/R mutation in the furin cleavage site of SARS-CoV-2 spike protein as being found in the B.1.1.7 variant. This has been corrected in the HTML and PDF versions of the manuscript to reflect that P681H/R is also found in the B.1.617 variant.

https://doi.org/10.1038/s41577-021-00560-9 I Published online 10 May 2021

๑) Springer Nature Limited 2021 